\title{
Effect of Ten Insecticidal Plant Powders on Rice Weevil, Sitophilus oryzae L. and Grain Weight Loss in Stored Sorghum
}

\author{
K. Govindan*, S. Geethanjali, S. Douressamy, M. Pandiyan and G. Brundha \\ Agricultural College and Research Institute, Valavachanur - 606 753, \\ Thiruvannamalai District, Tamil Nadu, India \\ *Corresponding author
}

\begin{tabular}{|l|}
\hline Ke y w o r d s \\
Plant powders, \\
$\begin{array}{l}\text { Sitophilus oryzae, } \\
\text { Sorghum grains }\end{array}$ \\
\hline Article Info \\
\hline $\begin{array}{l}\text { Accepted: } \\
23 \text { April } 2020 \\
\text { Available Online: } \\
\text { 10 May } 2020\end{array}$ \\
\hline
\end{tabular}

\begin{abstract}
A B S T R A C T
Laboratory studies were conducted at Department of Crop Protection, Agricultural College and Research Institute, Valavachanur - 606 753, Thiruvannamalai District to study the effect of plant powders tested against rice weevil, Sitophilus oryzae infesting sorghum. The experiment on ten plant powders 2 per cent, among them Acorus calamus 2 per cent rhizome powder was found to be significantly the best compared to other treatments. At four days after the treatment highest mortality was registered in A. squamosa 2 per cent (88.88\%) which was followed by Eclipta alba (51.11\%), C. indica (46.6 $6 \%$ ) and A. indica 2 per cent $(44.44 \%)$ and whereas untreated control recorded only 17.77 per cent. At six days after treatment highest mortality was seen in A. squamosa (98.88\%) followed by E. alba $(78.88 \%)$ while in control 36.66 per cent mortality was recorded and same trend was observed at 7 DAT. The experiment on adult emergence was nil in A. calamus 2 per cent rhizome powder treated sorghum grains while 97 adult rice weevils emerged from untreated control. No grain weight loss was recorded $A$. calamus 2 per cent rhizome powder treated sorghum grains. No grain weight loss was recorded A. calamus 2 per cent rhizome powder treated sorghum grains and 60 days after treatment while 47.25 per cent loss was registered in untreated control.
\end{abstract}

\section{Introduction}

Sorghum, Sorghum bicolor L. is called as 'Camel of crops' because of its hardiness and ability to withstand prolonged droughts. It is the fifth most important crop in the world after rice, wheat, corn and barley (Selva Rani et al., 2017). It accounts for an area of 8.9 million ha with production of 4.41 million tonnes in India and India is second largest producer of sorghum in the world (Pattanayak, 2016). Sorghum should be stored to meet home consumption as well as for sale.

About 80 per cent of all millet grain produced is estimated to be stored at farm or village level. Grater losses are inflicted during storage. In India storage losses have been estimated 14 million tones of food grains worth of Rs 7000 corers every year and 
storage insects alone causes Rs. 1300 corers (Suleiman and Rugumamu. 2017). Losses of food grains in the farmer holding in Tamil Nadu sorghum (16\%), rice $12.9 \%$ ) pearl millet (14\%) and maize (12. 7\%) (Annoymous, 2015).

Sorghum seeds are often traditionally stored in jute bags. This leads to significant increase of moisture during rainy seasons, thereby creating favourable conditions for grain weevil infestation (Hossain et al., 2007; Zunjare et al., 2014). Infested grain fetches lower market price due to reduced weight and nutritional value (Tefera, 2012). Seed viability of the damaged seed is drastically reduced and affects subsequent planting.

Stored sorghum are damaged by number of agents viz., insects, rodents, fungi, birds, mite and moisture, causing quantitative loss (quality deterioration by direct feeding on the grain, chemical changes in the grain content) and qualitative loss (loss in weight of stored millets). Stored sorghum and processed commodities are always at risk of the insect invasion and due to insect attack a progressive deterioration in quality and quantity results (Ukeh et al., 2012) the weight and germination capacity (Thomas et al., 2010).

After harvest the farmers usually store the seeds for longer periods. The ways the seeds are stored risk attack by storage insect pests. Sorghum and millets are mainly stored at household level by small farmers (Ukeh et al., 2012). The rice weevil Sitophilus oryzae L. (Colepotera: Curculionidae) is a serious pest of various food grains like rice, wheat and maize etc. under storage (Baloch, 1992). Rice weevil cause heavy losses of stored food grain quantitatively and qualitatively throughout the world (Arannilewa et al., 2002). Rice weevil, $S$. oryaze could spoil the quality of stored sorghum grains by as much as 100 per cent. Feeding by half-mature of $S$. oryaze often lead to most noticeable decline in germination in stored (Devi et al., 2014). Dubey et al., (2008) observed that the damage caused by $S$. oryaze and the loss of germination was significantly higher after five months of storage.

At present, pest control measures in storage rely on the use of synthetic insecticides and fumigants, which is the quickest and surest method of pest control but it is also not advised to mix the insecticides with food grains. Their indiscriminate use in the storage, however, has led to a number of problems including insect resistance, toxic residues in food grains (Fishwick, 1988), environmental pollution (WMO, 1995) and increasing costs of application.

In view of these problems together with the upcoming WTO regulations, there is a need to restrict their use globally and implement safe alternatives of conventional insecticides and fumigants to protect stored grains from insect infestations (Yusof and Ho, 1992; Subramanyam and Hagstrum, 1995).

Many synthetic insecticides have been found effective against stored product pests but proved to be hazardous to men and domestic animals. The over reliance on and nonjudicious use of synthetic pesticides especially insecticides since last four decades led to wide spectrum of pests problem like pests resistance to chemicals, resurgence of pests, residues in food and soil and risks to human and animal health, besides environmental pollution (Mohapatra and Gupta, 1998).

Ketkar (1986) reported that many plants possess activities against stored grain pests. In the present study twenty plant powders were tested for the mortality, adult emergence and seed weight loss against caused by $S$. oryzae infesting sorghum seeds. 


\section{Materials and Methods}

Laboratory studies were conducted at Department of Crop Protection, Agricultural College and Research Institute, Valavachanur - 606 753, Thiruvannamalai Disrtict to study the effect of twenty plant powders tested against rice weevil, $S$. oryzae infesting stored sorghum grains. Studies were conducted at during 2017-2018 to study the effect of various plant powders against $S$. oryzae.

\section{Rearing of test Insect}

Adults of $S$. oryzae were initially collected from villages of vanapuram, Perunduraipattu and Vazhavachanur infested stored sorghum seeds from the farmers. granaries and brought to the laboratory, at Department of Crop Protection, Agricultural College and Research Institute, Valavachanur - 606753 for mass culture further multiplied on paddy grains in plastic containers in the laboratory. S. oryzae were maintained at ambient laboratory temperature $\left(28 \pm 2^{\circ} \mathrm{C}\right)$ and relative humidity (70 $\pm 5 \%)$ conditions.

\section{Preparation of plant powders}

Insecticidal plants are indicated below in (Table 1) collected, washed with distilled water and shade dried at room temperature for seven days and crushed a pulverizer model of fritsch rotor speed mill pulverisette 14 with motor load is normal and rotational speed 14, $000 \mathrm{rpm}$ using in to fine powder using a pulveriser $(0.05 \mathrm{~mm}$ mesh sieve). All the powders were kept in plastic containers at room temperature and properly sealed to prevent quality loss and used for conducting experiments.

Laboratory experiments were conducted using ten plant dry powders against rice weevils, $S$. oryzae insecticidal action (per cent mortality), adult emergences and seed weight loss).
The experiment on insecticidal (per cent mortality) twenty grams of stored sorghum seeds were taken in plastic container powder of various plant parts at the rate of 2: 100 (w/w) was added to sorghum seeds and shaken thoroughly. Untreated check was maintained. Thirty newly emerged adults were released in to each plastic container and kept in laboratory.

Mortality (lack of locomotion and/ or response to repeated probing) was recorded at one day intervals for up to seven days. The experiment was laid out in Completely Randomized Design (CRD) with three replication were maintained for each treatments the per cent mortality (insecticidal action) compared with untreated control (Suleiman and Rugumamu, 2017).

In another experiment on adult emergence and seed weight losses were evaluated using ten plants, twenty grams of stored sorghum seeds were taken in glass bottles tightly closed with muslin cloth. The plant powder @ 2 per cent (w/w) were added to sorghum grains and shaken thoroughly. Then the glass bottles were covered firmly using muslin cloth.

Five pairs of newly emerged adults of $S$. oryzae were released to each glass bottle, covered firmly and kept in laboratory conditions as mentioned above at ambient conditions. Three replications were maintained for each treatment. On $20^{\text {th }}$ day after the release (DAR) of adult weevils all the dead insects were removed from the bottles to prevent them from mixing with first generation $\left(F_{1}\right)$ offspring. The number of newly emerged adults were counted and removed from the bottle once in every three days till the complete emergence of $F_{1}$ offspring. On 30, 45 and 60 day after the treatment (DAT) grain weight loss were taken and percentage was worked out as per the 
procedure followed (Suleiman and Rugumamu. 2017). The experiment was laid out in Completely Randomized Design (CRD) with three replication were maintained for each treatments.

\section{Statistical analysis}

The methods of Gomez and Gomez (1984) were followed in scrutinizing the data from various experiments. Square root and angular transformations were adopted for the data in numbers and percentage respectively (Abbott, 1925). Means in simple CRD analysis were separated by Duncan's multiple range test (Duncan, 1955).

\section{Results and Discussion}

Effect of plant powders on the adult mortality of Sitophilus oryaze

The results clearly indicated that all the treatments revealed a wide variation in mortality compared to untreated control (Table 2). The insecticidal action of first experiment powders of ten plants 2.00 per cent $(\mathrm{w} / \mathrm{w})$ were tested for their insecticidal action in comparison with untreated control. Data on mortality of $S$. oryaze after 1, 2, 3, 4, 5, 6 and 7 days after treatment (DAT) were recorded and furnished in Table 2.

Highest per cent mortality (35.55\%) was observed in Acorus calamus 2 per cent rhizome powder followed by Annona squamosa 2 per cent (11.11\%) and Acalypha indica 2 per cent $(5.55 \%)$ at 1 DAT, while in control no mortality was observed. Hence, the findings on $A$. calamus powder could be taken as a support for the present finding. Similarly, 97 per cent mortality has been reported with sweet flag rhizome powder treated against $S$. oryzae in sorghum (Gadewar et al., 2017). The results reported by Govindan and Jeyarajan Nelson (2009) found that the paddy grains treated with $A$. calamus rhizome powder 2 per cent which caused 86.22 per cent mortality to rice weevil at 4 days after treatments. Among the plant powder, 100.00 per mortality was registered in A. calamus 2 per cent followed by A. squamosa (71.10\%), A. indica $(24.44 \%)$ and $C$. indica $(24.44 \%)$ after 2 DAT.

Similar results reported by Selva Rani et al., (2017) who found that A. calamus rhizome powder caused cent per cent mortality to rice weevils at two days after treatment. This study confirmed by Rajeswari and Srinivasan (2019) who observed that A. calamus rhizome powder showed highest mortality to rice weevils.

At 3 DAT mortality was 75.55, 36.66 and 34.44 per cent in $A$. squamosa, $C$. indica and A. indica 2 per cent, respectively. At 4 DAT, highest mortality was observed in $A$. squamosa 2 per cent $(88.88 \%)$ which was followed by $E$. alba (51.11\%), C. indica (46.66 \%) and A. indica 2 per cent (44.44\%) and whereas untreated control recorded only 17.77 per cent mortality. Insecticidal action was well documented by Suleiman and Rugumamu, 2017 A. squamosa 2 per cent leaf powder recorded highest mortality of rice weevils in stored sorghum.

Maximum weevils dead in A. squamosa 2 per cent $(95.55 \%)$ at 5 DAT. At 6 DAT highest mortality was seen in $A$. squamosa 2 per cent (98.88\%) followed by E. alba 2 per cent (78.88\%) while in untreated control 36.66 per cent mortality was recorded.

The results of the experiment showed that the powders of plant leaves Annona squamosa destroyed almost all rice weevils by about 10th week after treatment Karunakaran et al., 2016. At 7 DAT, cent per cent mortality was seen in A. squamosa 2 per cent followed by Achyranthes aspera 2 per cent (89.99\%) 
whereas minimum mortality was observed in Cleome viscose and Coriandrum sativam 2 per cent $(48.88 \%)$. In untreated control 51.11 per cent mortality was recorded after 7 DAT. Among the botanicals Acorus calamus 2 per cent rhizome powder was significantly different from all other treatments. Results of Latha and Nagangoud, 2016 who observed that A. calamus caused highest mortality to rice weevils. However, present findings are in agreement with Padmasri et al., (2017) who reported that A. calamus rhizome powder @ $10 \mathrm{~g}$ per $\mathrm{kg}$ seed of maize seeds had recorded less infestation only ( 0.18 per cent) of rice weevils up to nine months of storage period and also Tiwari, (2018) observed that sweet flag, A. calamus dust highly effective and controlling the maize weevil, Sitophilus oryaze.

Effect of plant powder on adult emergence of Sitophilus oryaze and grain weight losses

Sitophilus oryaze significantly variable number of adult emerged on sorghum grains treated with ten plant powders in first experimental set up for adult weevil emergence and seed weight loss. No adult weevils emerged from Acorus calamus 2 per cent rhizome powder. Present findings line with finding of Padmasri et al., (2017) stated that Acorus calamus rhizome powder @ $10 \mathrm{~g}$ per of maize seeds had recorded less infestation of rice weevil damage $(0.18$ per cent), similar results recorded and cougmented by Tiwari, (2018) who stated that Acorus calamus rhizome powder treated maize seeds resulted less number adult emergence observed. Results reported by Govindan and Jeyarajan Nelson, (2009) observed that A. calamus rhizome powder 2 per cent treated paddy grains showed 14.44 adults weevils emerged. Next to Annona squamosa 2 per cent leaf powder (16.66 Nos), which was followed by Coriandrum sativam 2 per cent seed powder (18.00Nos) among the different plant powders highest adult weevils (49.00 Nos) was emerged from Acalypha indica 2 per cent leaf powder treated sorghum seeds, while 97 adult rice weevils emerged from untreated control. Acorus calamus was significantly superior to all other treatments in inhibiting the adult emergence of $S$. oryaze.

Table.1 The plant species evaluated against S. oryzae

\begin{tabular}{|l|l|l|l|l|}
\hline S. No & $\begin{array}{l}\text { Name of the } \\
\text { plants (Common } \\
\text { name) }\end{array}$ & $\begin{array}{l}\text { Name of the plants } \\
\text { (Scientific name } \text { ) }\end{array}$ & Family & Parts used \\
\hline 1. & Sweet flag & Acorus calamus L. & Aeraceae & Rhizomes \\
\hline 2. & Karisalakanni & Eclipta alba L. & Amranthaceae & Leaves \\
\hline 3. & Naiurivi & Achyranthes aspera L. & Amranthaceae & Leaves \\
\hline 4. & Custard apple & Annona squamosa L. & Annonaceae & Leaves \\
\hline 5. & Coriander & Coriandrum sativam L. & Apiaceae & Seeds \\
\hline 6. & Naikkaduku & Cleome viscosa L. & Capparidaceae & Leaves \\
\hline 7. & Kovai & Coccinia indica L. & Cucurbitaceae & Leaves \\
\hline 8. & Kuppaimani & Acalypha indica L. & Euphorbiaceae & Leaves \\
\hline 9. & Keelanelli & Phyllanthus niruri & Euphorbiaceae & Leaves \\
\hline 10. & Kolinji & Tephrosia purpurea L. & Fabaceae & Leaves \\
\hline
\end{tabular}


Table.2 Effect of plant powders on the mortality of rice weevil, Sitophilus oryzae in stored sorghum

\begin{tabular}{|c|c|c|c|c|c|c|c|c|c|}
\hline \multirow[t]{2}{*}{ S.No } & \multirow[t]{2}{*}{ Treatments } & \multicolumn{7}{|c|}{ Adult mortality ( \%) - Days after treatments (DAT)* } & \multirow[t]{2}{*}{ MEAN } \\
\hline & & 1 DAT & 2 DAT & 3 DAT & 4 DAT & 5DAT & 6 DAT & 7 DAT & \\
\hline 1 & Acorus calamus $2 \%$ & $\begin{array}{c}35.55 \\
(36.59)\end{array}$ & $\begin{array}{r}100.00) \\
(89.47)\end{array}$ & $\begin{array}{c}100.00 \\
(89.47)\end{array}$ & $\begin{array}{r}100.00 \\
(89.47)\end{array}$ & $\begin{array}{c}100.00 \\
(89.47)\end{array}$ & $\begin{array}{c}100.00 \\
(89.47)\end{array}$ & $\begin{array}{c}100.00 \\
(89.47)\end{array}$ & $\begin{array}{c}90.31 \\
(80.76)\end{array}$ \\
\hline 2 & Eclipta alba $2 \%$ & $\begin{array}{c}6.66 \\
(14.63)\end{array}$ & $\begin{array}{c}15.55 \\
(23.13)\end{array}$ & $\begin{array}{c}33.33 \\
(35.24)\end{array}$ & $\begin{array}{c}51.11 \\
(45.64)\end{array}$ & $\begin{array}{c}62.22 \\
(52.09)\end{array}$ & $\begin{array}{c}78.88 \\
(62.86)\end{array}$ & $\begin{array}{c}87.77 \\
(69.57)\end{array}$ & $\begin{array}{c}47.93 \\
(43.31)\end{array}$ \\
\hline 3 & Achyranthes aspera $2 \%$ & $\begin{array}{c}4.44 \\
(11.99)\end{array}$ & $\begin{array}{c}14.44 \\
(21.87)\end{array}$ & $\begin{array}{c}27.77 \\
(31.79)\end{array}$ & $\begin{array}{c}33.33 \\
(35.24)\end{array}$ & $\begin{array}{c}54.44 \\
(47.56)\end{array}$ & $\begin{array}{c}68.88 \\
(56.10)\end{array}$ & $\begin{array}{c}89.99 \\
(71.72)\end{array}$ & $\begin{array}{c}41.90 \\
(39.47)\end{array}$ \\
\hline 4 & Annona squamosa $2 \%$ & $\begin{array}{c}11.11 \\
(19.42)\end{array}$ & $\begin{array}{c}71.10 \\
(57.54)\end{array}$ & $\begin{array}{c}75.55 \\
(64.44)\end{array}$ & $\begin{array}{c}88.88 \\
(70.57)\end{array}$ & $\begin{array}{c}95.55 \\
(80.17)\end{array}$ & $\begin{array}{c}98.88 \\
(86.14)\end{array}$ & $\begin{array}{r}100.00 \\
(89.47)\end{array}$ & $\begin{array}{c}77.29 \\
(66.25)\end{array}$ \\
\hline 5 & Coriandrum sativam $2 \%$ & $\begin{array}{c}4.44 \\
(11.99)\end{array}$ & $\begin{array}{c}8.88 \\
(17.27)\end{array}$ & $\begin{array}{c}17.77 \\
(24.91)\end{array}$ & $\begin{array}{c}24.44 \\
(29.61)\end{array}$ & $\begin{array}{c}31.11 \\
(33.89)\end{array}$ & $\begin{array}{c}47.55 \\
(43.58)\end{array}$ & $\begin{array}{c}48.88 \\
(44.36)\end{array}$ & $\begin{array}{c}26.15 \\
(29.37)\end{array}$ \\
\hline 6 & Cleome viscosa $2 \%$ & $\begin{array}{c}0.00 \\
(0.52)\end{array}$ & $\begin{array}{c}12.22 \\
(20.32)\end{array}$ & $\begin{array}{c}15.55 \\
(23.19)\end{array}$ & $\begin{array}{c}28.88 \\
(32.50)\end{array}$ & $\begin{array}{c}36.66 \\
(37.26)\end{array}$ & $\begin{array}{c}41.10 \\
(39.86)\end{array}$ & $\begin{array}{c}48.88 \\
(44.36)\end{array}$ & $\begin{array}{c}26.18 \\
(28.29)\end{array}$ \\
\hline 7 & Coccinia indica $2 \%$ & $\begin{array}{c}5.55 \\
(13.47)\end{array}$ & $\begin{array}{c}24.44 \\
(29.55)\end{array}$ & $\begin{array}{c}36.66 \\
(37.25)\end{array}$ & $\begin{array}{c}46.66 \\
(43.08)\end{array}$ & $\begin{array}{c}57.77 \\
(49.49)\end{array}$ & $\begin{array}{c}68.88 \\
(56.19)\end{array}$ & $\begin{array}{c}75.55 \\
(60.44)\end{array}$ & $\begin{array}{c}45.07 \\
(41.35)\end{array}$ \\
\hline 8 & Acalypha indica $2 \%$ & $\begin{array}{c}5.55 \\
(13.47)\end{array}$ & $\begin{array}{c}24.44 \\
(29.55)\end{array}$ & $\begin{array}{c}34.44 \\
(35.93)\end{array}$ & $\begin{array}{c}44.44 \\
(41.80)\end{array}$ & $\begin{array}{c}56.66 \\
(48.83)\end{array}$ & $\begin{array}{c}66.66 \\
(54.75)\end{array}$ & $\begin{array}{c}75.55 \\
(60.37)\end{array}$ & $\begin{array}{c}43.96 \\
(40.68)\end{array}$ \\
\hline 9 & Phyllanthus niruri $2 \%$ & $\begin{array}{c}4.44 \\
(11.99)\end{array}$ & $\begin{array}{c}10.00 \\
(18.43)\end{array}$ & $\begin{array}{c}18.88 \\
(25.74)\end{array}$ & $\begin{array}{c}43.33 \\
(41.16)\end{array}$ & $\begin{array}{c}48.88 \\
(44.36)\end{array}$ & $\begin{array}{c}63.33 \\
(52.74)\end{array}$ & $\begin{array}{c}73.33 \\
(58.93)\end{array}$ & $\begin{array}{c}37.45 \\
(36.19)\end{array}$ \\
\hline 10 & Tephrosia purpurea $2 \%$ & $\begin{array}{c}3.33 \\
(8.66)\end{array}$ & $\begin{array}{c}23.32 \\
(28.75)\end{array}$ & $\begin{array}{c}25.55 \\
(30.35)\end{array}$ & $\begin{array}{c}34.44 \\
(35.93)\end{array}$ & $\begin{array}{c}42.21 \\
(40.50)\end{array}$ & $\begin{array}{c}55.55 \\
(48.21)\end{array}$ & $\begin{array}{c}67.77 \\
(55.41)\end{array}$ & $\begin{array}{c}36.02 \\
(35.40)\end{array}$ \\
\hline 11 & Untreated control & $\begin{array}{c}0.00 \\
(0.52)\end{array}$ & $\begin{array}{c}8.88 \\
(17.27)\end{array}$ & $\begin{array}{c}14.44 \\
(22.30)\end{array}$ & $\begin{array}{c}17.77 \\
(24.91)\end{array}$ & $\begin{array}{c}31.11 \\
(33.89)\end{array}$ & $\begin{array}{c}36.66 \\
(37.25)\end{array}$ & $\begin{array}{c}51.11 \\
(45.63)\end{array}$ & $\begin{array}{c}22.85 \\
(25.97)\end{array}$ \\
\hline
\end{tabular}

* Mean of three replication

Figures in parentheses are transformed arcsine values

DAT- Days after treatments

$\begin{array}{lcc} & \text { SED } & \text { CD }(0.05) \\ \text { Treatment } & 0.97 & 1.91 * * \\ \text { Period } & 0.74 & 1.46^{* *} \\ \text { Treatment x period } & 2.56 & 5.05^{* *}\end{array}$


Table.3 Effect of plant powder on adult emergence of Sitophilus oryzae and grain weight loss in sorghum

\begin{tabular}{|c|c|c|c|c|c|}
\hline \multirow{2}{*}{ S.No } & \multirow{2}{*}{ Treatments ${ }^{* * *}$} & \multirow{2}{*}{$\begin{array}{l}\text { No. of adults } \\
\text { emerged * }\end{array}$} & \multicolumn{3}{|c|}{ Grain weight loss (in \%) } \\
\hline & & & 30 DAT $* *$ & 45 DAT ** & 60 DAT $* *$ \\
\hline 1. & Acoruscalamus $2 \%$ & $\begin{array}{c}0.00 \\
(0.00) \mathrm{a}\end{array}$ & $\begin{array}{c}0.00 \\
(0.00) \mathrm{a}\end{array}$ & $\begin{array}{c}0.00 \\
(0.00) \mathrm{a}\end{array}$ & $\begin{array}{c}0.00 \\
(0.00) \mathrm{a}\end{array}$ \\
\hline 2. & Eclipta alba $2 \%$ & $\begin{array}{c}34.00 \\
(1.80) b c\end{array}$ & $\begin{array}{c}18.58 \\
(25.53) \mathrm{e}\end{array}$ & $\begin{array}{c}19.22 \\
(25.4)^{\mathrm{bc}}\end{array}$ & $\begin{array}{c}23.65 \\
(26.90)^{b}\end{array}$ \\
\hline 3. & Achyranthes aspera $2 \%$ & $\begin{array}{c}23.66 \\
(1.36) b\end{array}$ & $\begin{array}{c}12.11 \\
(20.30) b\end{array}$ & $\begin{array}{c}18.10 \\
(25.30)^{\mathrm{bc}}\end{array}$ & $\begin{array}{c}27.11 \\
(31.33)^{d}\end{array}$ \\
\hline 4. & Annona squamosa $2 \%$ & $\begin{array}{c}16.66 \\
(1.28) \mathrm{b}\end{array}$ & $\begin{array}{c}10.61 \\
(19.91) b\end{array}$ & $\begin{array}{c}17.15 \\
(25.33)^{b}\end{array}$ & $\begin{array}{l}20.90 \\
(26.9)^{\mathrm{b}}\end{array}$ \\
\hline 5. & Coriandrum sativam $2 \%$ & $\begin{array}{c}18.00 \\
(1.29) \mathrm{b}\end{array}$ & $\begin{array}{c}10.50 \\
(19.91) \mathrm{b}\end{array}$ & $\begin{array}{c}16.66 \\
(24.95)^{b}\end{array}$ & $\begin{array}{c}22.55 \\
(32.66)^{b}\end{array}$ \\
\hline 6. & Cleome viscosa $2 \%$ & $\begin{array}{c}31.00 \\
(1.51) b c\end{array}$ & $\begin{array}{c}17.80 \\
(25.41) b c\end{array}$ & $\begin{array}{c}18.11 \\
(25.33)^{\mathrm{bc}}\end{array}$ & $\begin{array}{c}27.11 \\
(30.33)^{c}\end{array}$ \\
\hline 7. & Coccinia indica $2 \%$ & $\begin{array}{c}24.66 \\
(1.42) \mathrm{b}\end{array}$ & $\begin{array}{c}15.86 \\
(23.41) b c\end{array}$ & $\begin{array}{c}20.99 \\
(26.96) c\end{array}$ & $\begin{array}{l}22.55 \\
(32.6)^{\mathrm{b}}\end{array}$ \\
\hline 8. & Acalypha indica $2 \%$ & $\begin{array}{l}49.00 \\
(1.70) \mathrm{d}\end{array}$ & $\begin{array}{c}18.80 \\
(23.41) b c\end{array}$ & $\begin{array}{c}23.66 \\
(26.90)_{\mathrm{d}}\end{array}$ & $\begin{array}{c}27.50 \\
(31.6) \mathrm{d}\end{array}$ \\
\hline 9. & Phyllanthus niruri $2 \%$ & $\begin{array}{c}33.33 \\
(1.54) b c\end{array}$ & $\begin{array}{c}16.86 \\
(23.41) b c\end{array}$ & $\begin{array}{c}28.22 \\
(31.77)^{\mathrm{e}}\end{array}$ & $\begin{array}{c}32.22 \\
(36.7)^{\mathrm{e}}\end{array}$ \\
\hline 10. & Tephrosia purpurea $2 \%$ & $\begin{array}{c}27.55 \\
(1.77) b c\end{array}$ & $\begin{array}{c}16.86 \\
(23.41) b c\end{array}$ & $\begin{array}{c}19.50 \\
(25.55)^{\mathrm{cd}}\end{array}$ & $\begin{array}{c}22.55 \\
(32.66)^{b}\end{array}$ \\
\hline 11. & Untreated control & $\begin{array}{l}97.00 \\
(2.07) \mathrm{e}\end{array}$ & $\begin{array}{c}34.26 \\
(35.82) d\end{array}$ & $\begin{array}{c}38.22 \\
(36.82)^{\mathrm{f}}\end{array}$ & $\begin{array}{c}47.25 \\
(46.80)^{d}\end{array}$ \\
\hline
\end{tabular}

DAT- Days after treatment

*Figures in parentheses are transformed square root transformed values

** Figures in parentheses are transformed arcsine values

*** Mean of three replication

In a column means followed by same letter(s) are not significantly different $(\mathrm{p}=0.05)$ by DMRT

The results of stored sorghum grain weight losses data presented in (Table 3). No grain weight loss was recorded Acorus calamus 2 per cent rhizome powder at 30 days after treatment. The results were in agreement the findings of Padmasri et al., (2017) concluded that the dose of A calamus rhizome powder @ $10 \mathrm{~g}$ per $\mathrm{kg}$ of maize seed had recorded only minimum weight loss (0.02 per cent) and protected up to nine months of the storage period. Annona squamosa 2 per cent leaf powder (10.61\%), Achyranthes aspera 2 per cent leaf powder (12.11\%) on par with Coriandrum sativam 2 per cent seed powder $(10.50 \%)$. In the rest of the treatments per cent seed infestation varied from 15. 86 to 18.80 per cent as against untreated control
(44.26\%). These findings are in corroboration with the findings Singh et. al, (2004); Govindan and Jeyarajan Nelson, (2009) and Khani et al., (2012) Acorus calamus 2 per cent rhizome powder was significantly superior than all other treatments in reduce the per cent grain weight loss in stored sorghum (Table 3 ).

Present finding line with Rajesh et al., (2017) who observed that sorghum seeds treated with sweet flag powder (2.5 per cent) less seed weight loss as compared to other botanicals seed treatment and untreated control during storage. At 45 DAT, minimum grain weight loss $(16.66 \%)$ observed in grain treated with Coriandrum sativam $2 \%$ seed powder which 
was followed by Annona squamosa $2 \%$ leaf powder (17.15\%), Achyranthes aspera 2 per cent leaf powder (18.10\%) and Eclipta alba 2 $\%$ leaf powder (19.22\%) treated sorghum grains. Present study already documented and confirmed by Karunakaran et al., (2016) who stated that two per cent Annona squamosa leaf powder admixed with paddy grains and stored for six months significantly reduced the percentage of damage caused $S$. oryzae during six months storage period.

Among the botanicals, highest to lowest per cent weight loss range viz., 20.99 per cent (Coccinia indica), 23.66 percent (Acalypha indica), 28.22 per cent (Phyllanthus niruri) were as compared to untreated control 38.22 per cent loss was observed in untreated control. At 60 DAT, minimum percentage of grain weight loss was observed in $A$. squamosa $(20.90 \%)$ which was on par with $C$. sativam (22.55\%), E. alba (23.65\%), Coccinia indica $(22.55 \%)$ (Table 3 ).

Asawalam et al., (2012) reported that the A. squamosa treated with rice protected up to two months from rice weevil. Several scientist tested their efficacy of sweet flag, A. calamus rhizome powder against the adults of S. oryzae (Sharma and Tiwari (2016) ; Paneru and Thapa 2018; Rajeswari and Srinivasan, 2019) and against Pulse beetle, C. maculatus (Shreelaxmi et al., 2017; Chandel et al., 2018; Dhivya et al., 2019)

Study the effect of twenty plant powders against $S$. oryzae infesting the stored sorghum the results revealed that the efficacy of various powders among them, Acorus calamus 2 per cent rhizome powder caused 100.00 per cent mortality to rice weevil 2 days after treatment. Acorus calamus powder complete inhibited egg laying and progeny development and also no weight losses recorded up to 60 days after treatment. Therefore, the resource poor farmers can use botanicals namely, sweet flag, Acorus calamus powder in controlling rice weevils is stored sorghum as they may not afford to buy chemical pesticides due to high cost. Furthermore, the use of botanical pesticides to control rice weevil is an appropriate strategy to avoid environmental pollution and other hazards, since the chemical pesticides are used by farmers and in agro industries currently.

\section{References}

Abbott, W.W. 1925. Amethod of computing the effectiveness of insecticide. $J$. Economic Entomology, 18: 265-265.

Annoymous, 2015. National millet development project 2013-2014 national symposium on millets and for sustainable agriculture, Directorate Research, TNAU, Coimbatore.

Arannilewa1, S. T., Ekrakene, T. and Akinney, J. O. 2006. Laboratory evaluation of four medicinal plants as protectants against the maize weevil, Sitophilus zeamais (Mots). African J. of Biotechnology, 5 (21): 2032-2036.

Asawalam, E. F., Ebere U. E and K Emeasor, C. 2012. Effect of some plant products on the control of rice weevil sitophilus oryzea (L.) Coleoptera: Curculionidae. J. of Medicinal Plants Res. 6(33): 48114814

Baloch, U. K. 1992. Integrated Pest Management in Food Grains. Food and Agriculture Organization of the United Nations and Pakistan Agricultural Research Council, Islamabad, Pakistan 117.

Chandel B.S., Indrani, D. Tewari. A. 2018. Screening of plant extract for insecticidal biopotency against Callosobruchus chinensis L. (Coleoptera:Bruchidae) on chickpea, Cicer aritenum L. Int. J. of Ento. Res. 3(1): 101-106. 
Devi. M., B., Victoria Devi, $\mathrm{N}$ and Noren Singh. S. 2014. Effects of Six Botanical Plant Powder Extracts on the control the rice weevil, Sitophilus oryzae L. in stored rice, Int. J. of Agriculture Innovations and Res. 2(5): 683-686.

Dhivya, V., Nelson, S. J. Subramanian, K.S, Edward Y.S.J.T, Rajamani, K. Santhanakrishnan V.P. and Sithanantham S. 2019. Development of Acorus calamus $\mathrm{L}$ nanoemulsion and their insecticidal activity against pulse beetle (Callosobruchus maculatus F.), Int. J. of Agriculture Sci., 11(9): 83878390.

Dubey, N. K., Srivastava B. and A. Kumar. 2008. Current status of plant products as botanical pesticides in storage pest management, J. of Biopesticide, 1( 2):182- 186 .

Duncan, D.B. 1995. Multiple range and multiple tests. Biometrics . 11 : 1-42.

Gadewar R, Babhulkar V, Lambat P. 2017. The influence of some botanicals against rice weevil during storage in rabi sorghum, Int. J. of Res. Biological Agriculture and Tech. 5(1):28-30.

Gomez, K.A. and Gomez. A.A. 1984. Statistical procedures for agricultural research, Wiley. Inter science publication , Jhon Wiley \& sons, Newyork, 680 p.

Govindan, K. and Jeyarajan Nelson S. 2009a. Insecticidal activity of plant powders on mortality, adult emergence of Sitophilus oryzae L. and grain weight loss in paddy $J$. of Plant Protec. and Environment, 6(1): 52.57.

Hossain, F., Boddupalli, P. M. Sharma, R. K. Kumar P. and Singh, B. B. 2007. Evaluation of quality protein maize genotypes for resistance to stored grain weevil Sitophilus oryzae (Coleoptera: Curculionidae). Int. J. of Tropical Insect Sci, 27: 114-121

Karunakaran, S. Prasannath K. and Shanika.
W. 2016. Insecticidal Activity of Plant Powders against Rice Weevil, Sitophilus oryzae L. (Coleoptera: Curculionidae). Int. J. of Res, 3(4): 425429.

Ketkar, C .M 1986. Use of tree derived non edible oils as surface protectants for stored grains against Sitophilus oryzae L. \& Ascher, K.R.S., ed, Proc. III rd International Neem Conferences July 1986, Nairobi, Kenya, pp. 535-542.

Khani, M., Muhamad Awang, R. Omar. D.2012. Insecticidal Effects of peppermint and black pepper essential oils against rice weevil, Sitophilus oryzae L. and Rice Moth, Corcyr cephalonica (St.), J. of Medicinal Plants, 43(11): 97-112.

Latha, H.C and Nagangoud, A. 2016. Bioassay of sweet flag, Acorus calamus (L.) on rice weevil, Siophilus oryzae L. Population. J. of Environment Ecology. 34 (3): 953- 956.

Mohapatra, G.K. and Gupta. G.P. 1998. Pesticide induced resurgence. Pestology, 22 (12): 14-20.

Padmasri, A., C. Srinivas, K. Vijaya Lakshmi, T. Pradeep, K. Rameash, Ch. Anuradha and B. Anil. 2017. Management of rice weevil (Sitophilus oryzae L.) in Maize by botanical seed treatments. Int.J.Curr.Microbiol.App.Sci, $\quad$ 6(12): 3543-3555.

Paneru R.B, and Thapa R.B. 2018. Efficacy of plant materials and storage containers against maize weevil, Sitophilus zeamais (Mots.) in maize storage. International Journal of Agriculture, Environment and Bioresearch 3(1): 119-128.

Pattanayak, 2016. Area, Production and Yield of Principal Crops. Agricultural statistic at a glance, 73-216.

Rajesh, G. Vipin, B, Prachi, L. 2017. The influence of some botanicals against rice weevil during storage in rabi 
sorghum. J. of Res. biosciences Agriculture and Tech., 5(1): 28-30.

Rajeswari, R and Srinivasan, M.R. 2019. Efficacy of different botanicals against Rice Weevil, Sitophilus oryzae L. (Coleoptera: Curculionidae) in stored paddy seeds, Madras Agric. J., 106 ( 79 ): 533- 136.

Selva Rani.S,, Justin, C. G. Gunasekaran K and Sheeba Joyce Roseleen, S. 2017. Efficacy of green synthesized silver nanoparticle, plant powders and oil against rice weevil Sitophilus oryzae L. (Coleoptera: Curculionidae) on sorghum seeds. J. of Pharmacognosy and Phytochemistry, 8(5): 38-42.

Sharma S and Tiwari S. (2016) Maize variety screening against maize weevil Sitophilus zeamais under Storage in Chitwan Condition of Nepal. Advances in Zoology and Botany 4(3): 31-36.

Shreelaxmi1, H. Sharanagouda1, C.T. Ramachandra1, R.S. Roopa1 and S.G. Hanchinal 2017. Supercritical Fluid Extraction of Oil from Sweet Flag Rhizome (Acorus calamus L.) and Its Insecticidal Activity on Pulse Beetles (Callosobruchus maculatus) , Int.J.Curr.Microbiol.App.Sci 6(10): 3608-3615.

Suleiman M and Rugumamu. C. P. 2017. Management of insect pests of stored sorghum using botanicals in Nigerian traditional stores, J. of Stored Products and Postharvest Research, 8 (9): 93-
102.

Suleiman M and Rugumamu. C. P. 2017. Management of insect pests of stored sorghum using botanicals in Nigerian traditional stores, J. of Stored Products and Postharvest Research, 8 (9): 93102.

Tefera, T. 2012. Post-harvest losses in Africa maize in face of increasing food shortage. Food Sec. 4: 267-277.

Thomas W, Phillips and Throne J. E. 2010. Biorational approaches managing stored product insects, Annual Review of Entomology, 55 (3): 375-379.

Tiwari, S. 2018. Evaluation of Repellent Plant Materials for Management of the Maize Weevil (Sitophilus zeamais) in Storage Condition, Int. J. Grad. Res. Rev. 5(1): 12-16.

Ukeh D.A, Oku, E.E. Udo I.A. and Ukeh. J.A. 2012. Insecticidal effect of fruit extract from Xylopia aethiopica and Dennettia tripetala (Annonaceae) against Sitophilus oryzae L. (Colepotera: Curculionidae). Chillean, J. of Agricultural Research, 72(2):195-200.

Zunjare, R., Hossain, F. Thirunavkkarasu, N., Muthusamy, V., Jha, S. K., Kumar, P. and Gupta, H. S. 2014. Evaluation of specialty corn inbreeds for responses to stored grain weevil (Sitophilus oryzae L.) infestation. Indian J. of Genetics and Plant Breeding. 74(4): 564-567.

\section{How to cite this article:}

Govindan, K., S. Geethanjali, S. Douressamy, M. Pandiyan and Brundha, G. 2020. Effect of Ten Insecticidal Plant Powders on Rice Weevil, Sitophilus oryzae L. and Grain Weight Loss in Stored Sorghum. Int.J.Curr.Microbiol.App.Sci. 9(05): 2700-2709. doi: https://doi.org/10.20546/ijcmas.2020.905.309 